\title{
Efficacy of non-specific hemostatic agents for reversal of prophylactic apixaban levels
}

\author{
K Schmidt $^{{ }^{*}}$, K Krüger $^{1}$, E Langer ${ }^{2}$, M Körber $^{1}$, C von Heymann ${ }^{1,3}$, K-D Wernecke $^{4}$ \\ From ESICM LIVES 2015 \\ Berlin, Germany. 3-7 October 2015
}

\section{Introduction}

Apixaban (Eliquis ${ }^{\mathbb{B}}$ ) is a direct and competitive inhibitor of factor FXa that is approved for thrombosis prophylaxis after hip and knee replacement surgery, in non-valvular atrial fibrillation and venous thromboembolic events therapy [1]. In cases of severe hemorrhages there is no approved specific antidote available to reverse the effect of apixaban yet. Previous animal and in vitro studies $[2,3]$ with supratherapeutic concentrations of apixaban (200ng $\mathrm{ml}^{-1}$ ) have shown that activated prothrombin complex concentrate (aPCC) and recombinant factor VIIa (rFVIIa) have a greater effect in reversing the effect of apixaban than prothrombin complex concentrate (PCC). The effect of these non-specific hemostatic agents for reversal of apixaban concentrations measured in patients after prophylactic doses (maximum observed plasma concentration $\left.62 \mathrm{ng} \mathrm{ml}^{-1}[4]\right)$ remains unclear.

\section{Objectives}

Evaluation of the efficacy of PCC, aPCC and rFVIIa for reversal of prophylactic concentration of apixaban induced alterations in hemostasis.

\section{Methods}

Blood samples from 10 healthy volunteers were spiked with apixaban in a corresponding dose of $2.5 \mathrm{mg}$ twice daily (4) and clinically relevant concentrations of PCC: Cofact $^{\circledR}: 25 \mathrm{IU} \mathrm{kg}^{-1}\left(0,35 \mathrm{IU} \mathrm{ml}^{-1}\right)$, aPCC: FEIBA ${ }^{\circledR} 25 \mathrm{IU}$ $\mathrm{kg}^{-1}\left(0,35 \mathrm{IU} \mathrm{ml}^{-1}\right)$ and rFVIIa: Novoseven ${ }^{\circledR} 90 \mu \mathrm{g} \mathrm{kg}^{-1}$ $\left(1 \mu \mathrm{g} \mathrm{ml}^{-1}\right)$. Tests were performed including thromboelastometry, prothrombin time (PT) and activated partial thromboplastin (aPTT). Statistical analysis was performed using non-parametric Wilcoxon pair-wise test.

\section{Results}

Apix-apixaban; Data are median (95\% confidence interval). " $\mathrm{p}<0,05$ vs. Control, \# $\mathrm{p}<0,05$ vs. apix

Prolongations in measured latency parameters were corrected by the different concentrates with variable efficacies (rFVIIa $\geq$ aPCC $>$ PCC). Addition of aPCC and rFVIIa to the spiked blood samples leads to overcorrection of PT, aPTT and CT-EXTEM.

\section{Conclusions}

Recombinant FVIIa and aPCC have the potential to restore the induced alterations in hemostasis of apixaban

Table 1

\begin{tabular}{|c|c|c|c|c|c|}
\hline & Control & apix & PCC $0,35 \mathrm{IU} \mathrm{ml-1}$ & aPCC $0,35 \mathrm{IU} \mathrm{ml}-1$ & rFVIla $1 \mu \mathrm{g} \mathrm{ml-1}$ \\
\hline apix ng ml-1 & 0 & 53 & 55 & 53 & 53 \\
\hline CT-EXTEM (s) & 70 & 78 & 78\# & $57^{*} \#$ & $52 * \#$ \\
\hline aPTT (s) & 34,6 & $37,0^{*}$ & $37,3^{*} \#$ & $32,9^{*} \#$ & $29,5^{*} \#$ \\
\hline PT (s) & 13,7 & $14,0^{*}$ & $13,0^{*} \#$ & $11,5^{*} \#$ & $9,0^{*} \#$ \\
\hline
\end{tabular}

${ }^{1}$ Charité University Medicine Berlin, Anaesthesiology, Berlin, Germany

Full list of author information is available at the end of the article 
in prophylactic dose in vitro. PCC showed partial effects only. The reversal effects of activated factor concentrates tend to overcorrection, which might be a risk for thrombotic events.

\section{Grant Acknowledgment}

Research Grant from Bristol-Myers Squibb/Pfizer.

\section{Authors' details}

'Charité University Medicine Berlin, Anaesthesiology, Berlin, Germany. 'Labor Berlin GmbH, Laboratory, Berlin, Germany. ${ }^{3}$ Vivantes Klinikum im

Friedrichshain, Anaesthesiology and Intensive Care, Berlin, Germany. ${ }^{4}$ Sostana $\mathrm{GmbH}$, Statistical Analysis, Berlin, Germany.

Published: 1 October 2015

\section{References}

1. [http://www.ema.europa.eu/docs/en_GB/document_library/EPAR_-

PProduct_Information/human/002148/WC500107728.pdf].

2. Escolar G, et al: PLoS One 8(11):e78696.

3. Martin AC, et al: J Thromb Haemost 2015, 13(3):426-36, Mar:

4. Frost C, et al: Br J Clin Pharmacol 2013, 76(5):776-86, Novi.

doi:10.1186/2197-425X-3-S1-A910

Cite this article as: Schmidt et al:: Efficacy of non-specific hemostatic agents for reversal of prophylactic apixaban levels. Intensive Care Medicine Experimental 2015 3(Suppl 1):A910.

\section{Submit your manuscript to a SpringerOpen ${ }^{\mathcal{D}}$ journal and benefit from:}

- Convenient online submission

- Rigorous peer review

- Immediate publication on acceptance

- Open access: articles freely available online

- High visibility within the field

- Retaining the copyright to your article 